\title{
Clio
}

Women, Gender, History

$38 \mid 2013$

Working Women, Working Men

\section{Wives, mothers, and property owners: women artisans in early modern Turin}

Épouses, mères et propriétaires : artisanes à Turin à l'époque moderne

\section{Beatrice Zucca Micheletto}

Translator. Anne Epstein

\section{OpenEdition}

\section{Journals}

\section{Electronic version}

URL: http://journals.openedition.org/cliowgh/317

DOI: 10.4000/cliowgh.317

ISSN: 2554-3822

Publisher

Belin

\section{Electronic reference}

Beatrice Zucca Micheletto, «Wives, mothers, and property owners: women artisans in early modern

Turin », Clio [Online], 38 | 2013, Online since 15 September 2014, connection on 20 April 2019. URL :

http://journals.openedition.org/cliowgh/317 ; DOI : 10.4000/cliowgh.317

Clio 


\title{
Wives, mothers, and property owners: women artisans in early modern Turin
}

\author{
Beatrice ZuCCA MiCHELETTO
}

"Angela Maria Negro, wife of Giuseppe Cora, affirms that she has always, for the past twenty-two years up to this day, exercised the craft of making silk and gold buttons, enabling her to support herself and her family, composed of eight children, a responsibility that the Father is unable to assume because he is too poor, earning his living as a servant, which is why the Supplicant was obliged to invest her dowry of 250 lire in the aforementioned button business. However, as she is not permitted to keep shop because she has not produced a masterwork, she must exercise the said craft using the name of a certified worker, whom she must pay exorbitantly for his products, making it impossible for the poor supplicant to provide for her large family when calamity strikes; and so, day after day, the aforementioned dowry has been shrinking; moreover, if she had to produce the masterwork, it would be at great expense, a hundred lire or more. Under such circumstances, therefore, the Supplicant has no other means to prevent the imminent depletion of her assets and to continue to make her living but to turn, as she has in fact done, to Your Majesty, and she was told to provide evidence to justify her claims, and to this effect such justification has been presented, as indicated in the certified documents dated the 16 and 21 March of last year signed by Franco and Pautriero, and upon whose honor and past appeal she prostrates herself again before Your Sacred and Royal Majesty, humbly pleading that His Majesty will, by exercising his special grace, after considering with benevolence the aforementioned circumstances and the unfortunate condition of the poor Supplicant, and her sincere will to earn her living through her labor, deign to exempt her from producing the masterwork required by the Memoriale a capi [statute] of the button manufacturers' University and if necessary, to make an exception to it as required in this case (...)."

"His Majesty, by an act of grace, in view of the circumstances described and the supplicant's long experience in the art of making gold, silver, and silk buttons, authorizes the Magistrate of the Consulate to permit her to exercise said craft, after confirming her skill through an oral examination 
or other test that he deems necessary for her to take, His Majesty having exempted her from the obligation to produce the masterwork and having made to that effect a special exception to $\int \mathbb{S} 3,4,5$, and 6 of the Memoriale a capi [statute] of the button manufacturers' University with responses approved by the Letters Patent of 16 March 1737. Turin, 16 July 1769."'

The document cited above is a plea drawn from a larger corpus held in the archives of the Consolato di Commercio of Turin. This plea, drafted in 1769 by a female button-maker, Angela Maria Negro, wife of Giuseppe Cora, was first sent to the King and then to the judges of the Consolato, in an effort to negotiate her admission to the urban guild. The Consolato was a judicial authority of both first instance and appeals, that oversaw economic activities, notably those connected with trade and the crafts regulated by the guilds. The judges were merchants and shopkeepers from the city and they were responsible for resolving conflicts among the artisan communities, in commerce, and in bankruptcy cases. The court also considered applications from aspiring masters. Relations with the King often led to conflict, and although the Consolato was supposed to follow royal instructions in economic matters, it nonetheless claimed a certain measure of autonomy. ${ }^{2}$ The archives of this magistracy, held in the Turin National Archives, contain all records of its activities (ordinances, sentences, guild registers). Here I will use Angela Maria Negro's plea as a starting point for understanding the multiple factors that shaped the identity of most women workers in Turin during the eighteenth century. Fewer women artisans were accepted or applied by petition for admission as guild members than exercised a trade outside of the guilds. Nonetheless, as we will see, Angela Negro's arguments convey via the written word a common sensibility and specific choices concerning the economic role of women in Turin society.

1 Archivio di Stato di Torino, sezioni riunite (henceforth AST, sez. riun.), Consolato di Commercio, Bottonaj, vol. 6. Text originally in Italian, here translated from the author's French version.

2 The history of the Consolato di Commercio and the conflicts in which it was involved during the eighteenth century have been reconstructed by Simona Cerutti 2003. 
Recalling the importance of women's guilds in Paris and their struggles to stay independent, Cynthia Truant has affirmed that the members of female corporations acquired an "authentic social standing" which, although hardly free of ambivalence and ambiguity, still gave them "an identity and a legal status different from that of other women workers." 3 The guild mistresses whom Truant studied clearly occupied a privileged position not seen in other socioeconomic and cultural contexts. Indeed, throughout the early modern period, contemporaries considered women's work not as a component of their identity, but simply as a duty. In Ancien Régime societies, everyone, man or woman, had to earn a living and contribute to the family's upkeep. Thus even if women worked, their occupation rarely contributed to the development of a specific identity: instead, their place in the family as daughters, wives or mothers defined their status. In Turin, women remained almost completely absent from the guilds (except for widows who had the right to continue the activity of their deceased husbands, as long as they employed a registered worker). The taffeta-weavers', buttonmakers', tailors' and ribbon-makers' guilds did admit mistressartisans, but they remained marginal; significantly, guild membership gave them neither the right to participate in assemblies nor the right to be nominated for positions of political responsibility. Nonetheless, women constituted a real and numerically significant presence in the local labor market. In eighteenth-century Turin, artisanal industry, and textile production in particular (from silk fabrics to accessories such as stockings, gloves, buttons, trimmings, ribbons and embroidered clothing), constituted one of the city's most crucial economic sectors, employing approximately $33 \%$ of the female labor force. ${ }^{4}$ Between the seventeenth and eighteenth centuries, inspired by

3 Truant 1996: 61.

4 Figure calculated by the author on the basis of Turin census data from 1802 concerning the total number of women aged over fifteen exercising a trade. The data was compiled into a database by a team of students led by M.C. Lamberti. I thank Signora Lamberti for allowing me to consult the database, which is maintained by the Department of Economic History of the University of Turin. See Lamberti 2002. 
the principles of Colbertism, the King's ministers invested heavily in silk. High quality silk thread was exported to international markets, while silk fabrics and other items were produced mainly for domestic consumption. ${ }^{5}$ At this time Turin was also a political center, as the seat of the royal court, the state bureaucracies, and chief religious institutions. These segments of society - together with the merchantbankers who had made their fortunes in the silk thread export business - fed the demand for luxury textile products. ${ }^{6}$ The document discussed here offers insight into the identity of the women workers of Turin, at least those engaged in artisanal production. At the same time, it alludes to the complexity and ambiguity of this identity, resulting from cultural and economic factors rooted in the local context.

The purpose of the plea was explicit: Angela Maria Negro sought membership in the button-makers' guild (perhaps even at the request of guild representatives?), with a reduction of the expense required to produce a masterwork. This plea must also be understood in the context of the reorganization of the Turin guilds (the "Universitä) that took place in the first half of the eighteenth century, at which time these corporations drafted official membership lists and asked the King to reinforce their privileges. ${ }^{7}$ At the time, a political conflict had divided the public authorities, notably the crown and the city government. Around the urban guilds, a significant portion of Turin society was consolidating its professional and social identity, and in particular was creating a new political identity from which women remained excluded. In March 1737, the gold, silver and silk button manufacturers had obtained an initial renewal of their statutes, which forbade "any person from working on their own, or with the help of laborers or apprentices, on any sort of gold or silver buttons (...) if the person has not made his masterwork and passed the test, on pain

5 Chicco 1995.

6 These same social groups also stimulated strong demand for domestic servants, making service occupations the second pillar of the city's economy.

7 Cerutti 1990. 
of a fine of a 24 gold ecus" (except widows) ${ }^{8}$. Nonetheless, after 1737 many female button-makers continued working without having taken the test. They had no interest in joining guilds that imposed fees and regulations on them while excluding them from political activities. Guild representatives denounced certain craftswomen, threatening to close down their operations and seize their assets. The craftswomen protested that their work allowed them to ensure "their own survival and that of their families." "The status of the button-makers was then clarified by a royal decree of 1740 that suspended all judicial proceedings against the women who had been denounced, granting them the right to work and to operate shops, as long as they declared their activity and paid the fees for the masterwork as soon as possible: in other words, if they accepted the guild rules. In practice, cases of women operating "unregulated" shops continued for decades to come, and the licensed manufacturers went on denouncing them. The women could not escape the corporation but had no intention of paying the sums demanded. So they decided to appeal to the King, using the plea to bring their cases to the attention of the Consolato di Commercio, in order to negotiate access to the guild under advantageous conditions. To strengthen her arguments, Angela decided to draw attention to certain specific aspects of her professional trajectory and life history.

Recent research has drawn attention to the "plea" as a particular form of legal document: historians concur on the complex nature of this source and the need to approach it with care. ${ }^{10}$ In a plea, the wish to present one's case as unique must be reconciled with the need to meet the expectations of the recipients, particularly as regards one's perceived social role. Consequently, by bringing together elements of self-representation, gender stereotypes reflecting contemporary perceptions of women's social role, and real biographical details,

8 «sia proibito a qualunque persona di travagliare o far travagliare per mezzo di lavoranti o apprendisti, alcuna sorta di detti bottoni d'oro o d'argento (...) se non avrà la persona fatto il capo d'opera e subito il dovuto esame sotto pena di scudi 25 d'oro », Duboin, vol. 17, 1818-1869: 149-154.

9 Duboin, vol. 17, 1818-1869: 154.

10 Van Voss 2001; Nubola \& Würgler 2002; Millet 2003; Cerutti 2010: 571. 
these texts give us a composite picture of the woman artisan of Turin. Angela Negro's petition demonstrates firstly that the identity of the woman worker remained associated with that of the mother and wife concerned for the well-being of her family. At the same time, this kind of reasoning is for Angela - as for other women artisans submitting pleas - a means of negotiating membership in the corporation. Secondly, this document suggests that dowries played a crucial role in the dynamics of the domestic economy and the workplace.

Let us now consider the text itself. Contrary to what we might imagine, Angela's petition gives no indication of her professional skill or experience. Only once, at the beginning of the text, does she recall that she has "always" worked at manufacturing buttons, "for 22 years". Nor does the King refer to Angela's competence in his response, but rather explains that she is to be exempted from producing a masterwork because of "the circumstances described and the supplicant's long practice of the craft of making gold, silver, and silk buttons". Yet even if her "long practice" needs no further explanation, the other "circumstances described" bear clarifying.

Angela's petition is rich in biographical details that evoke collective gender stereotypes. From the first lines, she explains that her work has "enabl[ed] her to support herself and her family, composed of eight children". The same theme recurs throughout the text: Angela must "provide for her large family" and "earn her living". This responsibility is all the more compelling as her husband cannot take care of the household "because he is too poor, earning his living as a servant". Suggesting that women's work played a central role in household survival strategies, Angela's words also hint at men's lack of job security. In Turin, domestic service was the most important employment sector for both men and women. As in other Italian cities, a large portion of the adult population held service jobs: ${ }^{11}$ although some men and women made real careers of domestic service, most moved from one employer to another, from one job to another. Angela's husband seemed to be no exception, for an earlier notarial document described him as a "cook", with no possessions and a salary

11 Arru 1992. 
of 5 lire per month. ${ }^{12}$ The precariousness of his situation thus made Angela's work indispensable. She doesn't hesitate to describe herself as "poor" several times. This poverty (along with that of her husband) refers to an overall situation of material and social instability that gives her the right to appeal to the King - who is here acting in the capacity of a benevolent father figure - and to benefit from his favors. All of these arguments are certainly founded, and are justified by the difficult situation of the Cora family and by the serious economic and social crisis the city was experiencing in the second half of the century. At the same time, they are put forward as an excuse by Angela who thus reframes the meaning of her trade and her identity as a worker within the "cage of the family economy". ${ }^{13}$ Her work and her professional profile are thus presented as subordinate to the social role society expects her to fill: to earn her living and support her family as a wife and mother. The conclusion of the petition returns to these arguments. Angela begs the King to exempt her from the masterwork on the grounds of "the wretched condition of the poor Supplicant and her sincere will to earn her living through her labor". It is interesting to note that Angela's words (and those of other women artisans in similar situations) are virtually the same as those women artisans had used over twenty years earlier in claims to the King about their bad treatment at the hands of the button-manufacturers (the complaint that resulted in the royal edict of 1740).

Angela also introduces another interesting element. By explaining that she had been "obliged to invest her dowry of 250 lire in the aforementioned button business", this woman artisan is also affirming that property forms an essential component of her identity. The women of Turin in fact possessed dowries that, while in theory inalienable, could be invested in an economic activity. This argument was not invented. In the second half of the eighteenth century, in the midst of an economic and social crisis, the alienation of dowries was widespread in Turin. This juridical procedure allowed spouses to convert a dowry into cash that could then be used to start up a commercial activity, to obtain supplies for a business or a shop, or to

\footnotetext{
12 AST, sez. riun., Insinuazione di Torino, a. 1760, 1. 10, ff. 7r-10v.
}

13 To borrow an apt term coined by Groppi 1996: 119-163. 
pay off debts. ${ }^{14}$ Angela Negro presented "certified documents" from Franco and Pautriero, the notaries in charge of registering alienation of dowries at the civil court of the Giudicatura. Searching by name at the city's notarial archives, I was able to locate the acts drafted at the conclusion of this procedure. These documents show that the alienation took place in two stages, well before the plea analyzed here was presented. The first half of the dowry (125 lire) was alienated in October 1756, that is, one month after the endowment act (dated September 1756); whereas the second part was requested in March 1758 and finally paid out in September 1760 (the plea itself was dated July 1769). ${ }^{15}$ Angela's reference to her dowry and its investment confirms her crucial economic role in sustaining the household, and above all enables her to justify her request by alluding to the risk of losing the capital derived from her dowry. Indeed, "as she is not permitted to keep a shop because she has not produced a masterwork, she must exercise the said craft using the name of a certified worker, whom she must pay exorbitantly for his products". Not only does this expense prevent her from "provid[ing] for" her family "when calamity strikes;" but it also presents the risk that "day after day, the aforementioned dowry [may] shrink". Moreover, she would incur the same loss of capital if she had to produce the masterwork, which "would be [a] great expense, a hundred lire or more" (thus causing the loss of at least half of her dowry). Here, Angela clearly evokes the risk for a woman of being left "indotata," that is, without a dowry. In this sense, the poverty she refers to - her "misfortune" - derives from the imminent possibility of losing the capital from her dowry. The reasoning is well conceived, as women were considered as "minors" in terms of property ownership, with Ancien Régime institutions as their ostensible guarantors. In Turin, as in other regions where Roman law prevailed, the endowment system was based on a matrimonial regime of separate property ownership. Upon marriage, a woman's property formally came under her husband's control, with the exception of items not part of the dowry

14 On the alienation of dowries see Zucca 2011a: 161-186; also Zucca 2011b and 2014.

15 AST, sez. riun., Insinuazione di Torino, a. 1760, 1. 10, ff. $7 r-10 v$, Quittanza delli Giuseppe ed Angela Maria gingali Cora a favore di Bartolomeo Uscello per lire 112 soldi 10. 
that remained in her possession, including property inherited from her own family or assets acquired through her own labor. ${ }^{16}$ Thus to eliminate the risk of any misuse by the husband, alienation of the dowry had to take place before a judge, with explicit consent of the woman and a commitment by the couple that the dowry would be used to sustain the household. Often notarial deeds contained creditors' receipts attesting to the appropriate use of the capital from the dowry. ${ }^{17}$

Two conclusions emerge from this analysis of the source. First, Angela's plea demonstrates that women could (and knew how to) negotiate a place for themselves in the working world by using arguments that explicitly evoked their role in the family economy, and alluded to the risk of being left without a dowry. Using precisely this kind of reasoning - on the one hand drawing on stereotypes about women and on the other hand referring to the threat of downward social and economic mobility (more feared than real) - Angela was able to negotiate her way into the guild under favorable conditions. ${ }^{18}$ Thus the king exempted her from the requirement to produce a masterwork, by overriding certain sections of the statutes of the button-makers' guild; but she was to be admitted to the guild (that is, she would have the right to practice her trade and to keep a shop) only after an oral examination (or an abbreviated practical test, at the discretion of the Consolato). In conclusion, Angela must accept membership in the community of button-makers in order to pursue her work; but her multiple identities of wife and mother, worker, and property owner helped her to negotiate admission to the guild.

Second, the plea suggests that property ownership was even more essential to the identity of women workers of Turin than was their membership in a trade corporation. The dowry, an indispensable requirement for marriage, played a key role in the economy and in labor market participation, because it could be invested in a

\footnotetext{
16 That is, when the woman is "industriosa" (industrious). See Ago 1996: 172.

17 Zucca 2011a: 169-171.

18 These same dynamics appeared in eighteenth-century Rome in struggles between the tailors' guild on the one hand, women and Jews on the other. See Groppi 2002a: 137-161.
} 
commercial activity that would ensure the sustenance of both the woman and her family. We may then ask if and how women's property ownership affected power relations between the sexes (particularly between husbands and wives). In other words, it is very likely that the potential uses of dowries within households gave women a certain power of expression and negotiation to counter husbands' authority within marriage. The story of Angela Negro also suggests that if we are to ask new questions and renew our approaches to women's work, we must explore more fully the relation between work and property. Where did women find the means to engage in economic activities? How did they set themselves up? What were the consequences? These questions, still underexplored in the historiography, ${ }^{19}$ are crucial, because they allow us to conceive of frontiers and hierarchies in the world of women's work beyond the dichotomy mistress/worker. Understanding the relationship between work and property is also crucial for our comprehension of certain dynamics of today's society. The spread of micro-credit is a good example. As we know, micro-credit is a system of financing aimed at individuals too poor or too weak to have access to banking networks. Very significantly, women wishing to set up or improve a business enterprise are the most frequent beneficiaries of these circuits, both in Europe and in the poorer countries of the planet. ${ }^{20}$ This suggests that even today, the relationship between work and property remains problematic.

Translated by Anne EPSTEIN

\section{Bibliography}

AgO, Renata. 1996. Oltre la dote. I beni femminili. In Il lavoro delle donne, ed. Angela GroppI, 164-182. Rome-Bari: Laterza.

ARru, Angiolina. 1992. Servi e serve: le particolarità del caso italiano. In Storia della famiglia italiana 1750-1950, ed. David KerTZER and Richard SALLER, 273-306. Bologna: Il Mulino.

19 See for example Groppi 1996 and 2002b.

20 Sen 1999: chapter 8. 
CerutTi, Simona.1990. La Ville et les métiers: naissance d'un langage corporatif. Turin 17 e $^{-}$ $18^{e}$ siècle. Paris: Éditions de l'EHESS.

- 2003. Giustizia sommaria: pratiche e ideali di giustižia in una società di Ancien Régime (Torino XVIII secolo). Milan: Feltrinelli.

- 2010. Travail, mobilité et légitimité. Suppliques au roi dans une société d'Ancien Régime(Turin, XVIII ${ }^{\mathrm{e}}$ siècle). Annales Histoire, Sciences Sociales 65(3): 571-611.

CHICco, Giuseppe. 1995. La Seta in Piemonte 1650-1800. Milan: F. Angeli.

Duboin, Felice Amato. 1818-1896. Raccolta per ordine di materie delle leggi, cioè patenti, manifesti ecc. pubblicate sino all'8 dicembre 1789 sotto il felicissimo dominio della Real Casa di Savoia (...) compilata dall'avvocato Felice Amato Duboin. Turin: Marcio Tip.

GroppI, Angela. 1996. Lavoro e proprietà delle donne in età moderna. In Il Lavoro delle donne, ed. Angela GroppI, 119-163. Rome-Bari: Laterza.

- 2002a. Une ressource légale pour une pratique illégale. Les juifs et les femmes contre la corporation des tailleurs dans la Rome pontificale (XVII - -XVIII ${ }^{\mathrm{e}}$ siècle). In The V alue of the Norm, ed. Renata AgO, 137-161. Rome: Biblink.

- 2002b. A matter of fact rather than principle: women, work and property in papal Rome (eighteenth-nineteenth centuries). Journal of Modern Italian Studies 7(1): 37-55.

LAMBERTI, Maria Carla. 2002. Una fonte "vecchia" per nuovi problemi: i censimenti per lo studio della mobilità in età preindustriale. Quaderni Storici XXXVII: 545-552.

Millet, Hélène (ed.). 2003. Suppliques et requêtes. Le gouvernement par la grâce en Occident (XII ${ }^{e}-X V^{e}$ siècle). Rome: Éditions de l'École Française de Rome.

NubolA, Cecilia, and Andreas Würgler (ed.). 2002. Suppliche e "gravamina". Politica, amministrazione, giustizia in Europa (secoli XIV-XVIII). Bologna: Il Mulino.

SEN, Amartya. 1999. Development as Freedom. Oxford: Oxford University Press.

Truant, Cynthia. 1996. La maitrise d'une identité? Corporations féminines à Paris aux XVII et XVIII siècles. CLIO. Histoire, Femmes et Sociétés 3: 55-69.

VAN Voss, Lex Heerma (ed.). 2001. Petitions in Social History. International Review of Social History, supplement no. 9.

Zucca Micheletto, Beatrice. 2011a. À quoi sert la dot? Aliénations dotales, économie familiale et stratégies des couples à Turin au XVIII siècle. Annales de Démographie Historique: 161-186.

- 2011b. Reconsidering the southern Europe model: dowry, women's work and marriage patterns in pre-industrial urban Italy (Turin, second half of the $18^{\text {th }}$ century). The History of the Family 16(4): 354-370.

- 2014. Travail et propriété des femmes en temps de crise (Turin, XVIII ${ }^{\mathrm{e}}$ siècle). Mont-Saint-Aignan: Presses universitaires Rouen-Le Havre. 